\title{
PERENCANAAN KEMBALI TEBAL PERKERASAN JALAN BETON BERTULANG MENERUS DENGAN METODE AASHTO 1993 DAN EVALUASI CRACK (STUDI KASUS RUAS JALAN TOL BALARAJA KM. 34+500 - 36+300)
}

\author{
oleh : \\ Muhammad Fakhruriza Pradana \\ Teknik Sipil Universitas Sultan Ageng Tirtayasa \\ Email: mfakhruriza@untirta.ac.id \\ Rindu Twidi Bethary \\ Teknik Sipil Universitas Sultan Ageng Tirtayasa \\ Email: rindubethary@untirta.ac.id \\ Siti Hadiyati Rohmah \\ Teknik Sipil Universitas Sultan Ageng Tirtayasa \\ Email: sitihadiyati@rocketmail.com
}

\begin{abstract}
Abstrak: Ruas tol Balaraja Barat - Cikupa merupakan jalur transportasi dan jalur pengiriman barang antarkota yang strategis penghubung provinsi Banten dengan DKI Jakarta. Ruas tol tersebut mempunyai volume lalu lintas yang padat dan sering mengalami kemacetan pada jam-jam sibuk. Sehingga, diperlukan perencanaan tebal perkerasan yang tepat, efisien serta optimal agar dapat mengakomodir beban yang melintas diatasnya serta sesuai dengan umur rencana jalan tersebut. Penelitian ini memiliki tujuan untuk merencanakan kembali tebal perkerasan jalan beton bertulang menerus dengan metode AASHTO dan evaluasi $\mathrm{crack} / \mathrm{retak}$ dari data existing lapangan dan data hasil perencanaan serta menganalisa hasil keduanya dengan bantuan software Hiperpav 3.2. Hasil yang diperoleh tebal perkerasan beton bertulang menerus dengan menggunakan metode AASHTO 1993 yaitu sebesar $28 \mathrm{~cm}$, sambungan memanjang (tie bar) didapat diameter $13 \mathrm{~mm}$ dengan jarak $900 \mathrm{~mm}$. Hasil perancangan tulangan memanjang menghasilkan diameter tulangan memanjang $16 \mathrm{~mm}$ dan jarak $100 \mathrm{~mm}$ serta tulangan melintang dimeter $13 \mathrm{~mm}$ dengan jarak $900 \mathrm{~mm}$. Dari hasil analisa data existing dengan tebal perkerasan $23 \mathrm{~cm}$ menggunakan software Hiperpav 3.2 diperoleh nilai rata-rata jarak crack 2,98 ft dan nilai rata-rata lebar crack adalah 0,027 in Sedangkan, hasil analisa data perencanaan dengan tebal perkerasan $28 \mathrm{~cm}$ menggunakan software Hiperpav 3.2. diperoleh nilai rata-rata jarak crack 2,72 ft dan nilai rata-rata lebar crack didapat 0,022 in. Dari hasil perbandingan evaluasi crack yang terjadi semakin besar tebal perkerasan beton maka crack yang terjadi akan semakin kecil.
\end{abstract}

Kata Kunci : Crack, Perkerasan, Rigid, Tebal, Tol

Abstract: West Balaraja toll road - Cikupa is transport and delivery of goods intercity lines connecting strategic Banten province to Jakarta. The toll road has heavy traffic volume and is often congested on the hour - rush hour. Thus, the required thickness of pavement proper planning, efficient and optimized to accommodate the burden of passing above and by the design life of the road. This study has the objective to re-plan the thick continuously reinforced concrete pavement with AASHTO methods and evaluation of existing crack of the data field and the data and analyze the results of the planning results both with the help of software Hiperpav 3.2. Results obtained continuously reinforced concrete pavement thickness using the AASHTO 1993 method is $28 \mathrm{~cm}$, longitudinal joint (tie-bars) obtained a diameter of $13 \mathrm{~mm}$ with a distance of $900 \mathrm{~mm}$. Results of longitudinal reinforcement design produce a longitudinal reinforcement diameter of 16 
$\mathrm{mm}$ and a distance of $100 \mathrm{~mm}$ and transverse reinforcement diameter $13 \mathrm{~mm}$ at a distance of $900 \mathrm{~mm}$. From the data analysis with the existing pavement thickness of $23 \mathrm{~cm}$ using Hiperpav 3.2 software obtained an average value of $2.98 \mathrm{ft}$ crack distance and the average value of the crack width is 0,027 in hand, the data analysis plan with pavement thickness of $28 \mathrm{~cm}$ using software Hiperpav 3.2, obtained an average value of $2.72 \mathrm{ft}$ crack distance and the average value of the crack width obtained 0.022 in. From the results of comparative evaluation of crack which occurs the greater the thickness of concrete pavement crack that occurs will be smaller.

Keywords : Crack, Pavement, Rigid, Tickness, Toll

\section{Pendahuluan}

Perkembangan Provinsi Banten yang semakin berkembang dengan laju pertumbuhan lalu lintasnya menjadi semakin tinggi sehingga kegiatan rutinitas masyarakat yang melalui jalan di Provinsi Banten terutama di jalan tol Tangerang Merak, khususnya ruas tol Balaraja Barat Cikupa. Ruas tol Balaraja Barat - Cikupa mempunyai volume lalu lintas yang padat dan sering mengalami kemacetan pada jamjam sibuk.

Pentingnya fungsi jalan dalam kehidupan manusia telah mendorong untuk pertimbangan pemilihan tipe perkerasan yang akan digunakan untuk dapat merencanakan perkerasan jalan secara lebih efektif dan efisien.

\section{Tujuan dan Lokasi Penelitian}

Adapun tujuan dari penelitian ini akan dijabarkan sebagai berikut:

1. Menghasilkan tebal perkerasan beton bertulang menerus.

2. Mengetahui besar jarak retak/crack dan lebar crack yang terjadi.

Lokasi penelitian pada ruas jalan Tol Balaraja - Cikupa Km 34+500 - 36+300 arah Jakarta.

\section{Tinjauan Pustaka}

Menurut Undang-undang No. 38/2004, jalan adalah prasarana transportasi darat yang meliputi segala bagian jalan termasuk bangunan pelengkap dan perlengkapannya yang diperuntukkan bagi lalu lintas, yang berada pada permukaan tanah, di atas permukaan tanah, di bawah permukaan tanah dan/atau air, serta di atas permukaan air, kecuali jalan kereta api, jalan lori, dan jalan kabel. Macam-macam jalan dibedakan menjadi tiga macam, yaitu:

1. Jalan umum

2. Jalan khusus

3. Jalan tol

Berdasarkan bahan ikat, lapisan perkerasan terbagi menjadi tiga kategori, yaitu:

1. Lapisan perkerasan lentur

2. Lapisan perkerasan kaku

3. Lapisan perkerasan komposit

Berdasarkan adanya sambungan dan tulangan plat beton perkerasan kaku dapat diklasifikasikan menjadi 3 jenis, yaitu:

1. Perkerasan beton tak bertulang bersambungan/Jointed plain concrete pavement (JPCP)

2. Perkerasan beton bertulang bersambungan/Jointed reinforced concrete pavement (JRCP)

3. Perkerasan beton bertulang menerus/ Continuously reinforced concrete pavement (CRCP)

Beton bertulang menerus merupakan perkerasan beton yang tulangan dan panjang pelatnya dibuat menerus tanpa sambungan melintang. Umumnya, perkerasan beton bertulang menerus 
mempunyai tulangan lebih banyak dan sambungan-sambungan hanya dibutuhkan untuk keperluan pelaksanaan. Jarak tulangan dibuat lebih rapat, karena tulangan berfungsi untuk mendistribusikan crack agar seragam disepanjang perkerasan. Selain itu, tulangan juga untuk mencegah timbulnya crack yang terlalu lebar.

\section{Kriteria Perencanaan Perkerasan Beton Bertulang Menerus Metode AASHTO 1993}

Parameter-parameter perancangan dalam perencanaan tebal pelat beton adalah:

a. Menetapkan umur rancangan

b. Perancangan lalu lintas, Equivalent single axle load (ESAL)

c. Menetapkan faktor distribusi arah dan lajur $\left(\mathrm{F}_{\mathrm{D}}\right.$ dan $\left.\mathrm{F}_{\mathrm{L}}\right)$

d. Menghitung pertumbuhan lalu lintas

e. Menetapkan kemampuan pelayanan

f. Menetapkan reliabilitas

g. Menetapkan deviasi standar normal menggunakan tabel di bawah ini

Tabel 1. Hubungan antara $R$ dengan ZR

\begin{tabular}{|c|c|}
\hline $\mathrm{R}(\%)$ & $\mathrm{Z}_{\mathrm{R}}$ \\
\hline 50 & 0 \\
\hline 60 & $-0,253$ \\
\hline 70 & $-0,524$ \\
\hline 75 & $-0,674$ \\
\hline 80 & $-0,841$ \\
\hline 85 & $-1,037$ \\
\hline 90 & $-1,282$ \\
\hline 91 & $-1,340$ \\
\hline 92 & $-1,405$ \\
\hline 93 & $-1,476$ \\
\hline
\end{tabular}

\begin{tabular}{|c|c|}
\hline 94 & $-1,555$ \\
\hline 95 & $-1,645$ \\
\hline 96 & $-1,751$ \\
\hline 97 & $-1,881$ \\
\hline 98 & $-2,054$ \\
\hline 99 & $-2,327$ \\
\hline 99,9 & $-3,09$ \\
\hline 99,99 & $-3,75$ \\
\hline
\end{tabular}

Sumber: AASHTO, 1993

h. Menetapkan deviasi standar Keseluruhan

Penetapan ini harus memenuhi syarat perkerasan kaku dengan nilai $\mathrm{S}_{0}$ diantara 0,3-0,4

i. Menghitung modulus reaksi tanah dasar efektif (k)

$$
\begin{gathered}
\mathrm{k}=\frac{\mathrm{MR}}{19,4} \text { dengan } \\
\mathrm{MR}=1500 \times \text { Nilai CBR }
\end{gathered}
$$

dimana:

$\mathrm{k} \quad=$ modulus reaksi tanah dasar

MR = modulus resilient

$\mathrm{CBR}$ = nilai CBR lapangan

j. Menghitung modulus elastisitas beton dan modulus lentur beton

$$
\begin{gathered}
E_{c}=57000\left(f^{\prime}{ }_{c}\right)^{0.5} \\
\operatorname{dan} S_{c}^{\prime}=7,5\left(f^{\prime}{ }_{c}\right)^{0.5}
\end{gathered}
$$

dengan:

$\mathrm{Ec}=$ modulus elastis beton (Psi)

$\mathrm{f}^{\prime} \mathrm{c}=$ kuat tekan beton semen (Psi)

$\mathrm{S}^{\prime} \mathrm{c}=$ modulus lentur beton (Psi)

k. Menetapkan koefisien drainase

Penetapan koefisien drainase mengikuti tabel 2 berikut.

Tabel 2. Rekomendasi Nilai Koefisien Drainase $\left(\mathrm{C}_{\mathrm{d}}\right)$

\begin{tabular}{|l|l|l|l|l|}
\multirow{2}{*}{\multicolumn{1}{c|}{ Mutu drainase }} & \multicolumn{3}{|c|}{ Persen waktu dimana perkerasan berada dalam kelembaban mendekati } \\
\cline { 2 - 5 } & \multicolumn{1}{|c|}{$1 \%$} & $1-5 \%$ & $5-25 \%$ & $>25 \%$ \\
\hline Sangat Baik & $1.25-1.20$ & $1.20-1.15$ & $1.15-1.10$ & 1.10 \\
\hline Baik & $1.20-1.15$ & $1.15-1.10$ & $1.10-1.00$ & 1.00 \\
\hline Cukup & $1.15-1.10$ & $1.10-1.00$ & $1.00-0.90$ & 0.90 \\
\hline Kurang & $1.10-1.00$ & $1.00-0.90$ & $0.90-0.80$ & 0.80 \\
\hline
\end{tabular}




\begin{tabular}{|l|c|c|c|c|}
\hline \multirow{2}{*}{ Mutu drainase } & \multicolumn{4}{|c|}{ Persen waktu dimana perkerasan berada dalam kelembaban mendekati } \\
& $1 \%$ & $1-5 \%$ & $5-25 \%$ & $>25 \%$ \\
\cline { 2 - 5 } & $1.00-0.90$ & $0.90-0.80$ & $0.80-0.70$ & 0.70 \\
\hline Sangat Kurang & \multicolumn{4}{|c|}{} \\
\hline
\end{tabular}

Sumber: AASHTO, 1993

l. Menetapkan koefisien penyaluran beban (J)

Perhitungan koefisien penyaluran

beban mengikuti standar AASHTO, 1993 seperti pada tabel 3 berikut ini.

Tabel 3. Koefisien Penyaluran Beban

\begin{tabular}{|l|l|l|l|l|}
\hline \multicolumn{4}{|c|}{ Bahu } & \multicolumn{2}{c|}{ Aspal } & Perkerasan Beton Bersambung \\
\hline Alat Pelimpahan Beban & Ya & Tidak & Ya & Tidak \\
\hline \multicolumn{5}{|c|}{ Jeis Perkerasan } \\
\hline 1. Sambungan Biasa Dengan Bertulang & 3,2 & $3,8-4,4$ & $2,5-3,1$ & $3,6-4,2$ \\
\hline 2. Beton Bertulang & $2,9-3,2$ & N/A & $2,3-2,9$ & N/A \\
\hline
\end{tabular}

Sumber: AASHTO, 1993

Rumus yang digunakan pada perhitungan tebal pelat adalah

$$
\begin{gathered}
\log _{10} \mathrm{~W}_{18}=\mathrm{Z}_{\mathrm{R}} \mathrm{S}_{\mathrm{o}}+7,35 \log _{10}(\mathrm{D}+1)-0,06+\frac{\log _{10}\left[\frac{\Delta \mathrm{PSI}}{4,5-1,5}\right]}{1+\frac{1,624 \times 10^{7}}{(\mathrm{D}+1)^{8,46}}}+\left(4,22-0,32 \mathrm{p}_{\mathrm{t}}\right) \\
\times \log _{10} \frac{\mathrm{S}_{\mathrm{c}} \mathrm{C}_{\mathrm{d}} \times\left[\mathrm{D}^{0,75}-1,132\right]}{215,63 \times \mathrm{J} \times\left(\mathrm{D}^{0.75}-\frac{18,42}{\left.\left(\frac{\mathrm{E}_{\mathrm{c}}}{\mathrm{k}}\right)^{0,25}\right)}\right.}
\end{gathered}
$$

dengan:

$\mathrm{D}=$ Tebal pelat beton

$\mathrm{W}_{18}=$ Beban sumbu standar total (ESAL) selama umur rencana

$\Delta$ PSI $=$ Kemampuan pelayanan

So = Deviasi standar keseluruhan

$\mathrm{ZR}=$ Konstranta pada nilai reliabilitas

$\mathrm{IPt}=$ Indeks permukaan

$\mathrm{S}^{\prime} \mathrm{C}=$ Modulus keruntuhan beton

$\mathrm{Cd}=$ Koefisien drainase

$\mathrm{J}=$ Koefisien penyaluran beban

$\mathrm{Ec}=$ Modulus elastisitas beton (psi)

$\mathrm{k}=$ Modulus reaksi tanah (pci)

Perancangan sambungan dan tulangan

a. Menghitung tie bar

$$
\text { As }=\frac{W D F L P}{f s}
$$

dengan:

As = luas penampang tulangan

$\mathrm{W}$ = berat volume pelat beton

$\mathrm{F} \quad=$ koefisien gesek antara dasar pelat dan permukaan lapis pondasi bawah

$\mathrm{D}=$ tebal pelat beton

$\mathrm{L} \quad=$ lebar perkerasan

$\mathrm{P} \quad=$ panjang perkerasan

Fs = tegangan tarik ijin tulangan baja

Panjang tie bar ditentukan dari persamaan (Fwa dan Wei, 2006)

$$
\mathrm{l}=2\left(\frac{A s \times f s}{U a \times S}\right)+\delta
$$

dengan:

$1 \quad$ = panjang tie bar

As = luas tampang tie bar

Fs = tegangan tarik ijin tulangan baja 
$U a=$ tegangan lekat ijin

$$
\left(1.97 * \sqrt{f^{\prime} c}\right) * 14,22 \text { (psi) }
$$

$\mathrm{S} \quad=$ keliling tulangan tie bar

$\delta=$ jarak kelongggaran $(0,05)$

b. Menetapkan koefisien gesek

Koefisien gesek dihitung menggunakan tabel 4.

Tabel 4. Koefisien Gesek (F)

\begin{tabular}{|l|l|}
\hline \multicolumn{1}{|c|}{$\begin{array}{c}\text { Tipe } \\
\text { material di } \\
\text { bawah } \\
\text { pelat beton }\end{array}$} & F \\
\hline Permukaan & 2 \\
\hline Stabilisasi & 8 \\
\hline Stabilisasi & 8 \\
\hline Stabilisasi & 8 \\
\hline Koral & 5 \\
\hline Batu Pecah & 5 \\
\hline Batu pasir & 2 \\
\hline Tanah & 9 \\
\hline
\end{tabular}

Sumber: AASHTO, 1993

c. Menetapkan sifat baja

Tabel 5 digunakan untuk menetapkan sifat baja berdasarkan kuat luluh dan kuat tarik ijin dari baja.

Tabel 5. Kuat Luluh \& Tarik Ijin Baja

\begin{tabular}{|l|r|r|}
\hline Tipe & Fy (psi) & Fs (psi) \\
\hline Grade 40 & 40.000 & 30.000 \\
\hline Grade 60 & 60.000 & 45.000 \\
\hline $\begin{array}{l}\text { Welded wire fabric } \\
\text { (WWF) }\end{array}$ & 65.000 & 48.750 \\
\hline $\begin{array}{l}\text { Deformed wire } \\
\text { fabric (DWF) }\end{array}$ & 65.000 & 48.750 \\
\hline
\end{tabular}

Sumber: AASHTO, 1993

d. Menghitung kebutuhan tulangan memanjang

1) Tulangan yang dibutuhkan untuk mengendalikan jarak crack di antara 3,5 $\mathrm{ft}-8 \mathrm{ft}$

$$
\bar{x}=\frac{1.32\left(1+\frac{\mathrm{ft}}{1000}\right)^{6.7} \times\left(1+\frac{\alpha \mathrm{s}}{\alpha c}\right)^{1.15} \times(1+\theta)^{2.19}}{\left(1+\frac{\sigma \mathrm{w}}{1000}\right)^{5.20} \times(1+\mathrm{P})^{4.40} \times(1+1000 \mathrm{Z})^{1.79}}
$$

Rumus tersebut terhubung dengan tabel 6 dan tabel 7 untuk mendapatkan nilai koefisien susut dan koefisien termal berdasakan kuat tarik beton dan macam agregat kasar yang digunakan.

\section{Tabel 6. Koefisisen Susut Beton}

\begin{tabular}{|c|c|}
\hline $\begin{array}{c}\text { Kuat tarik tak } \\
\text { langsung beton, Ft } \\
\text { (psi) }\end{array}$ & $\begin{array}{c}\text { Koefisien susut } \\
\text { beton, z (in/in) }\end{array}$ \\
\hline 300 atau kurang & 0,00080 \\
\hline 400 & 0,00060 \\
\hline 500 & 0,00045 \\
\hline 600 & 0,00030 \\
\hline 700 atau lebih & 0,00020 \\
\hline
\end{tabular}

Sumber: AASHTO,1993

Tabel 7. Koefisien Termal Beton

\begin{tabular}{|l|c|}
\hline \multicolumn{1}{|c|}{$\begin{array}{c}\text { Macam } \\
\text { agregat kasar }\end{array}$} & $\begin{array}{c}\text { Koefisien termal beton, } \\
\alpha_{\mathrm{c}}\left(1 /{ }^{\circ} \mathrm{F}\right)\end{array}$ \\
\hline Quartz & 0,0000066 \\
\hline Batu pasir & 0,0000065 \\
\hline Kerikil & 0,0000060 \\
\hline Granit & 0,0000053 \\
\hline Basalt & 0,0000048 \\
\hline Batu gamping & 0,0000038 \\
\hline
\end{tabular}

Sumber: AASHTO,1993

2) Tulangan yang dibutuhkan untuk mengendalikan lebar crack 0,04 in

$$
\mathrm{Cw}=\frac{0.00932\left(1+\frac{\mathrm{ft}}{1000}\right)^{6,53} \times(1+\theta)^{2,2}}{\left(1+\frac{\sigma \mathrm{w}}{1000}\right)^{4,91} \times(1+\mathrm{P})^{4,55}}
$$

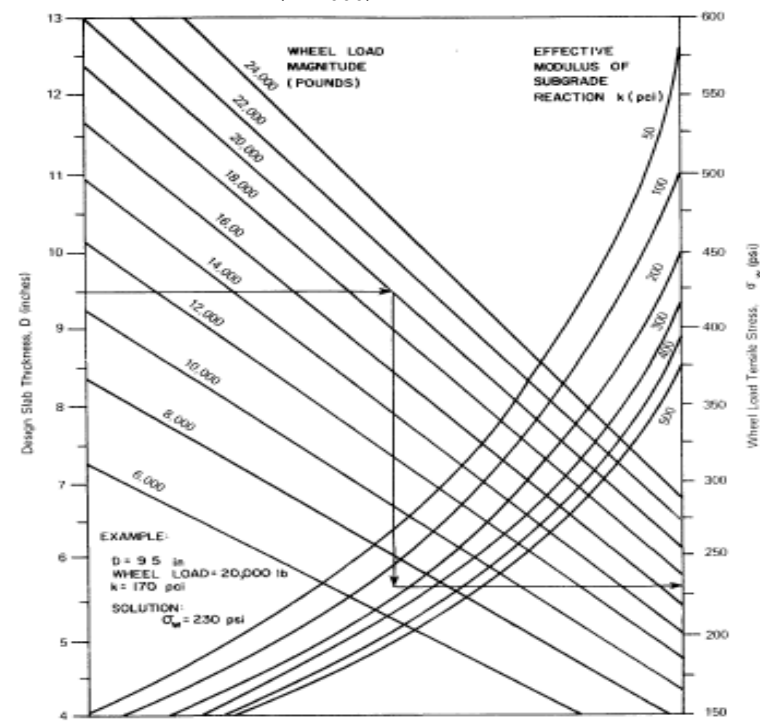

Gambar 1. Grafik untuk Menentukan Tegangan Tarik akibat Beban Roda, $\sigma w$ 
3) Tulangan yang dibutuhkan untuk mengendalikan tegangan berlebih.

$$
\sigma s=\frac{47,3\left(1+\frac{\mathrm{DTd}}{100}\right)^{0,42} \times\left(1+\frac{\mathrm{ft}}{1000}\right)^{4,09}}{\left(1+\frac{\sigma \mathrm{w}}{1000}\right)^{3,14} \times(1+\mathrm{P})^{2,74} \times(1+1000 \mathrm{Z})^{0,494}}
$$

Perhitungan tulangan yang dibutuhkan untuk mengendalikan tegangan berlebih dilakukan menggunakan rumus di atas dengan bantuan tabel 8 .

Jumlah tulangan minimum

$$
\mathrm{N}_{\min } \quad=\frac{0,01273 \times \mathrm{Pmin} \times \mathrm{D} \times \mathrm{b}}{\mathrm{d}^{2}}
$$

Jumlah tulangan maksimum

$$
\mathrm{N}_{\max }=\frac{0,01273 \times P \max \times \mathrm{D} \times \mathrm{b}}{\mathrm{d}^{2}}
$$

dengan:

$\mathrm{d}=$ diameter tulangan (in)

$\mathrm{P}_{\max }=$ persen maksimum tulangan yang dibutuhkan

$\mathrm{P}_{\min }=$ persen minimum tulangan yang dibutuhkan

D = tebal pelat beton (in)

$\mathrm{b} \quad=$ lebar pelat perkerasan (in)

\section{Tabel 8. Tarik Ijin Untuk Tulangan Baja}

\begin{tabular}{|c|c|c|c|}
\hline $\begin{array}{c}\text { Kuat tarik } \\
\text { tak } \\
\text { langsung } \\
\text { beton,28 } \\
\text { hari (psi) }\end{array}$ & \multicolumn{2}{|c|}{$\begin{array}{c}\text { Tegangan kerja ijin/ kuat } \\
\text { tarik ijin (fs) untuk } \\
\text { tulangan Grade 60, fs }= \\
45.000 \text { psi }\end{array}$} \\
\cline { 2 - 4 } & $\begin{array}{c}\text { Dia 1/2” } \\
\text { (No 4) }\end{array}$ & $\begin{array}{l}\text { Dia 5/8"| } \\
\text { (No 5) }\end{array}$ & $\begin{array}{l}\text { Dia 3/4" } \\
\text { (No 6) }\end{array}$ \\
\hline 300 & 65.000 & 57.000 & 54.000 \\
\hline 400 & 67.000 & 60.000 & 55.000 \\
\hline 500 & 67.000 & 61.000 & 56.000 \\
\hline 600 & 67.000 & 63.000 & 58.000 \\
\hline 700 & 67.000 & 65.000 & 59.000 \\
\hline 800 & 67.000 & 67.000 & 60.000 \\
\hline
\end{tabular}

Sumber: AASHTO,1993

e. Menghitung kebutuhan tulangan melintang

$$
\mathrm{Ps}=\frac{\mathrm{LFW}}{2 \mathrm{fs}} \times 100
$$

dengan:

Ps = persen tulangan yang dibutuhkan (\%)

$\mathrm{L} \quad=$ panjang pelat $(\mathrm{ft})$

$\mathrm{F} \quad=$ koefisien gesek

$\mathrm{W}$ = berat volume pelat beton (pci)

Fs = tegangan tarik ijin tulangan baja (psi)

Jarak antar tulangan melintang

$$
\mathrm{Y}=\frac{A S}{P S \times D} \times 100
$$

dengan:

$$
\begin{aligned}
& \mathrm{Y}=\text { jarak antar tulangan melintang (in) } \\
& \text { As }=\text { luas penampang tulangan }\left(\mathrm{in}^{2}\right) \\
& \mathrm{D}=\text { tebal pelat beton (in) } \\
& \mathrm{Ps}=\text { persen tulangan yang dibutuhkan }
\end{aligned}
$$
$(\%)$

\section{Evaluasi crack pada Perkerasan Beton Bertulang Menerus}

Penelitian ini mengevaluasi jarak crack dan lebar crack. Jarak crack terdiri dari crack memanjang dan melintang. Sedangkan, lebar crack terdiri dari gompal, penurunan atau patahan, crack tambahan serta punchout.

\section{Software Hiperpav 3.2}

Sistem HIPERPAV® 3.2 dikembangkan sebagai alat untuk memprediksi kerusakan perkerasan kaku baik JPCP, JRCP dan CRCP. Pada sistem ini dapat mengetahui kemampuan prediktif untuk konsultan, kontraktor, dan pemasok beton agar dapat mengidentifikasi faktor-faktor yang dapat berkontribusi untuk mencapai perkerasan yang baik. Hal ini penting untuk mengenali berbagai faktor yang mempengaruhi kinerja perkerasan beton. HIPERPAV 3.2 dapat digunakan untuk mengoptimalkan desain perkerasan sehingga peningkatan kinerja perkerasan jangka panjang dapat dicapai. 


\section{Metodologi Penelitian}

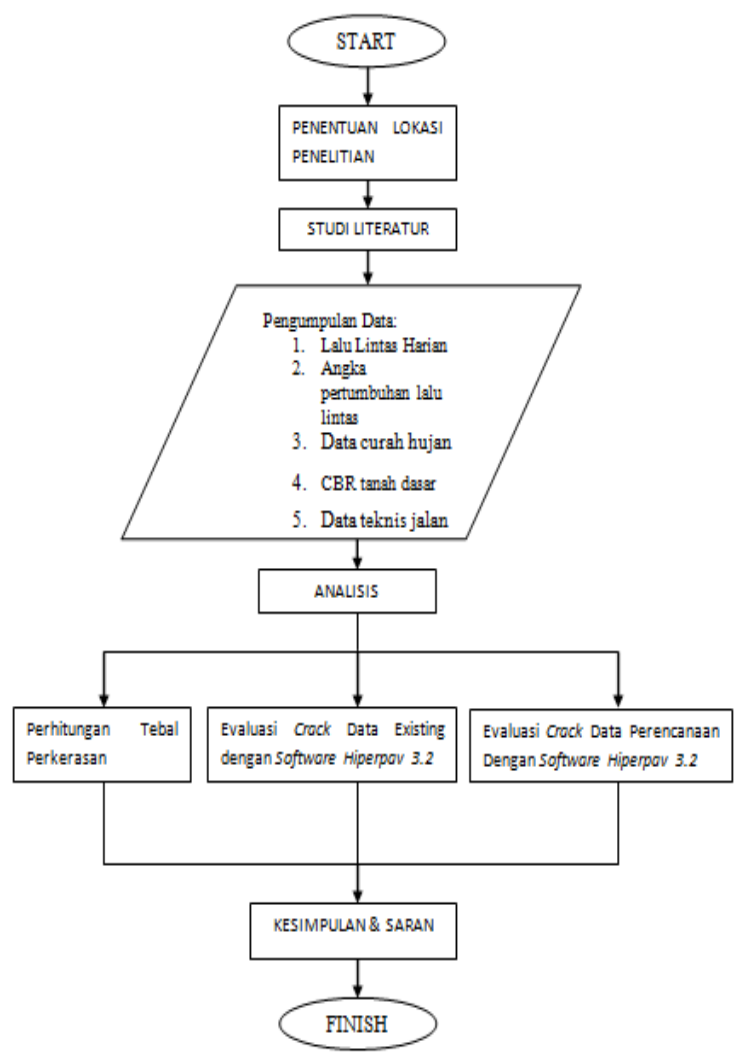

Gambar 2. Flowchart Penelitian

\section{Perhitungan Tebal Perkerasan Beton dengan Metode AASHTO 1993}

Parameter yang diketahui:
a. Klasifikasi jalan : bebas hambatan
b. Fungsi jalan : rural (luar kota)
c. Umur rencana : 20 Tahun
d. CBR : $6 \%$
e. Mutu beton : FS 45
f. Kuat tekan beton $500 \mathrm{~kg} / \mathrm{cm}^{2}$

g. Pertumbuhan lalu lintas didapat $8,18 \%$ per tahun

Langkah-langkah perhitungan tebal perkerasan dapat dilihat pada bagian dibawah ini.

1. Perhitungan ESAL rancangan

Perhitungan ESAL rancangan dapat dilihat pada tabel 9, sehingga didapatkan

$$
\begin{aligned}
\mathrm{W}_{18} & =\sum F_{D} \times F_{L} \times V_{i} \times E k_{i} \\
& =0,5 \times 0,7 \times 511.511 .135,09 \\
& =179.028 .897,28 \\
& =1,7902 \times 10^{8}(\text { ESAL })
\end{aligned}
$$

2. Kehilangan kemampuan pelayanan

Tingkat pelayanan awal, Po $=4,5$ dan tingkat pelayanan akhir, $\mathrm{Pt}=2,5 . \Delta \mathrm{PSI}=$ $4,5-2,5=2,0$

3. Reliabilitas digunakan $85 \%$

4. Standar normal deviasi adalah ZR = 0,1037

5. Standar deviasi keseluruhan adalah So $=$ 0,3

6. Modulus Resillient (MR) $=9000 \mathrm{psi}$

7. Modulus reaksi tanah dasar $(\mathrm{k})=464$ pci

8. Modulus elastisitas beton (Ec) = 4806286,508 psi

9. Modulus lentur beton $\left(\mathrm{S}^{\prime} \mathrm{c}\right)=632,40 \mathrm{psi}$

10. Koefisien drainase $(\mathrm{Cd})$ dengan keadaan kualitas drainase antara good - fair ditetapkan 1,2.

Coba tebal pelat 11 in

$$
\begin{aligned}
& \log _{10} 1,7902 \times 10^{8}=[-1,037 \times 0,30]+7,35 \log _{10}(11+1)-0,06+\frac{\log _{10}\left[\frac{4,5-2,5}{4,5-1,5}\right]}{1+\frac{1,624 \times 10^{7}}{(11+1)^{8,46}}}+(4,22-0,32 \times 2,5) 632 \times 1,2 \times\left[11^{0,75}-1,132\right] \\
&\left.\times \log _{10} \frac{63,63 \times \mathrm{J} \times\left(11^{0.75}-\frac{18,42}{\left(\frac{4806287}{464}\right)^{0,25}}\right)}{215}\right)
\end{aligned}
$$

Jadi, tebal perkerasan didapatkan sebesar 11 in $=28 \mathrm{~cm}$. 
Tabel 9. ESAL Rancangan

\begin{tabular}{|l|c|c|c|c|}
\hline \multicolumn{1}{|c|}{ Tipe Kendaraan } & Lalu Lintas & $\begin{array}{c}\text { Faktor } \\
\text { Ekivalensi }\end{array}$ & $\begin{array}{c}\text { ESAL } \\
(2015)\end{array}$ & $\begin{array}{c}\text { ESAL Rancangan } \\
(2035)\end{array}$ \\
\hline \multicolumn{1}{|c|}{1} & 2 & 3 & $4=(2 \times 3 \times a)$ & $6=(4 x b)$ \\
\hline Mobil Penumpang & 15.163 & 0,0004 & $2.213,798$ & $103.380,67$ \\
\hline Pick Up (1.1) & 3.718 & 0,247 & $335.196,290$ & $15.653 .107,48$ \\
\hline Bus Besar (1.2) & 794 & 0,3006 & $87.116,886$ & $4.068 .213,22$ \\
\hline Bus Kecil (1.2) & 160 & 0,247 & $14.424,800$ & $673.614,09$ \\
\hline Truk Sedang (1.2 M) & 5.084 & 1,3084 & $2.427 .945,544$ & $113.381 .005,96$ \\
\hline Truk Berat (1.2 H) & 1583 & 3,0022 & $1.395 .894,941$ & $81.005 .547,94$ \\
\hline Truk Tandem (1.22) & 2.289 & 3,7918 & $3.167 .992,023$ & $147.939 .941,79$ \\
\hline Truk Gandeng (1.2-2.2) & 161 & 3,9083 & $229.671,249$ & $10.725 .264,15$ \\
\hline Truk Semi Trailer (1.2-22) & 973 & 4,1891 & $1.388 .013,204$ & $69.474 .878,60$ \\
\hline Truk Trailer (1.22-222) & 721 & 5,5728 & $1.097 .871,747$ & $68.486 .181,18$ \\
\hline \multicolumn{3}{|r|}{ Total } & $511.511 .135,09$ \\
\hline
\end{tabular}

Sumber: Analisa, 2015

11. Perancangan sambungan dan tulangan Diketahui data sebagai berikut :

- Tebal pelat $(D)=11 \mathrm{in}=28 \mathrm{~cm}$

- Lebar pelat (L) = 3,6 m = 144 in

- Panjang pelat $(P)=75 \mathrm{~m}=2952,9$ in

- $\quad$ Koefisien gesek $(F)=1,8$

- Berat volume beton $(\mathrm{W})=25 \mathrm{kN} / \mathrm{m}^{3}$ $=0,09 \mathrm{pci}$

- Baja di pilih Grade 60 dengan nilai Fy $=60.000 \mathrm{psi}$

a. Sambungan tie bar

Diameter tie bar

$$
\begin{aligned}
& \text { As }=\frac{\text { WDFLP }}{\mathrm{fs}}=\frac{(0.09 \times 11 \times 1.8 \times 144 \times 2952,9)}{45000} \\
&=0,1719 \mathrm{in}^{2} \mathrm{maka} \\
& \mathrm{d}=0,5 \mathrm{in} \\
& \text { panjang tie } b a r \\
& \mathrm{l} \quad=2\left(\frac{A s \times f s}{\text { Ua } \times S}\right)+\delta \\
&=2\left(\frac{0,1719 \times 45.000}{626,399 \times 1,57}\right)+0,05 \\
&=15,79 \mathrm{in}=401 \mathrm{~mm}
\end{aligned}
$$

Jarak antar tie bar

Tie bar dengan jarak pendekat 3,6 m (12 $\mathrm{ft}$ ) Jarak maksimum tie bar adalah 36 in $=900 \mathrm{~mm}$. Jumlah tulangan per $75 \mathrm{~m}=$ $75000 \mathrm{~mm}=\frac{75000}{900}=83,3 \approx 83$ buah.

b. Perancangan tulangan memanjang

Tulangan yang dipilih $\emptyset 5 / 8$ in (d) = 16 $\mathrm{mm}$

Diketahui:
- Kuat tarik ijin fs $\quad=45000$ psi

- Kuat tarik beton tak langsung 28 hari $=640 \mathrm{psi}$

- Penyusutan beton (z) $=0.0003$ in/in

- Koefisien ekspansi termal beton dari bahan kerikil $(\alpha c)=0.000006$ in/in $/{ }^{\circ} \mathrm{F}$

- Koefisien ekspansi termal baja $(\alpha \mathrm{s})=$ $0.000005 \mathrm{in} / \mathrm{in} /{ }^{\circ} \mathrm{F}$

- Beban roda maksimum $=24000 \mathrm{lb}$

- Modulus reaksi tanah dasar efektif= 464

- Penurunan temperatur $=55^{\circ} \mathrm{F}$

Hitungan tulangan memanjang dengan syarat: $\mathrm{P}_{\max 1}>\mathrm{P}_{\min }$

1. Tulangan yang dibutuhkan untuk mengendalikan jarak crack diantara 3,5 ft $-8 \mathrm{ft}$

$\bar{x}=\frac{1.32\left(1+\frac{\mathrm{ft}}{1000}\right)^{6.7} \times\left(1+\frac{\alpha \mathrm{s}}{\alpha \mathrm{c}}\right)^{1.15} \times(1+\theta)^{2.19}}{\left(1+\frac{\sigma \mathrm{w}}{1000}\right)^{5.20} \times(1+\mathrm{P})^{4.40} \times(1+1000 \mathrm{Z})^{1.79}}$

$\alpha \mathrm{s} / \alpha \mathrm{c}=0.83$

$\bar{x}=3,5 \mathrm{ft}$ didapat $\mathrm{P}_{\max }=0,791$ dan $\bar{x}=8$ $\mathrm{ft}$ didapat $\mathrm{P}=0,496$

2. Tulangan yang dibutuhkan untuk mengendalikan lebar crack 0.04 in

$$
\begin{aligned}
& \mathrm{Cw}=\frac{0.00932\left(1+\frac{\mathrm{ft}}{1000}\right)^{6,53} \times(1+\theta)^{2,2}}{\left(1+\frac{\sigma \mathrm{w}}{1000}\right)^{4,91} \times(1+\mathrm{P})^{4,55}} \\
& \sigma w=200 \mathrm{psi} \\
& \mathrm{Cw}=0,04 \text { in didapat } \mathrm{P}=0,535
\end{aligned}
$$


3. Tulangan yang dibutuhkan untuk mengendalikan tegangan berlebih.

$\sigma S=\frac{47,3\left(1+\frac{\mathrm{DTd}}{100}\right)^{0,42} \times\left(1+\frac{\mathrm{ft}}{1000}\right)^{4,09}}{\left(1+\frac{\sigma \mathrm{W}}{1000}\right)^{3,14} \times(1+\mathrm{P})^{2,74} \times(1+1000 \mathrm{Z})^{0,494}}$

$\sigma$ s dengan $\emptyset 5 / 8$ di dapat $65 \mathrm{ksi}$ (Tabel

19). Sehingga $P=0,543$.

Check syarat: $\mathrm{P}_{\max 1}>\mathrm{P}_{\min }$

$0,791>0,543$ ...OK

Jumlah tulangan

$\mathrm{N}_{\min }=\frac{0,01273 \times 0,543 \times 11 \times 144}{0,625^{2}}=28$

$\mathrm{N}_{\max }=\frac{0,01273 \times 0,791 \times 11 \times 144}{0,625^{2}}=41$

Jadi, untuk lebar 3,6 m digunakan 36 buah, dengan jarak antar tulangan $100 \mathrm{~mm}$.

c. Perancangan tulangan melintang

Coba $\emptyset \frac{1}{2}$ in = $13 \mathrm{~mm}$ untuk tulangan melintang

$$
\begin{aligned}
\text { Ps } & =\frac{L F W}{2 \mathrm{fs}} \times 100 \\
& =\frac{246,075 \times 1,8 \times 0.09}{90.000} \times 100=0,04 \%
\end{aligned}
$$

Jarak antar tulangan melintang

$$
\begin{aligned}
Y & =\frac{0,171}{0,044 \times 11} \times 100 \\
& =35,29 \mathrm{in} \\
& =896,47 \mathrm{~mm} \approx 900 \mathrm{~mm}
\end{aligned}
$$

Jadi, untuk panjang $75 \mathrm{~m}$ dengan jarak antar tulangan $900 \mathrm{~mm}=83,3 \approx 83$ buah.

d. Gambar potongan melintang dan memanjang

e.

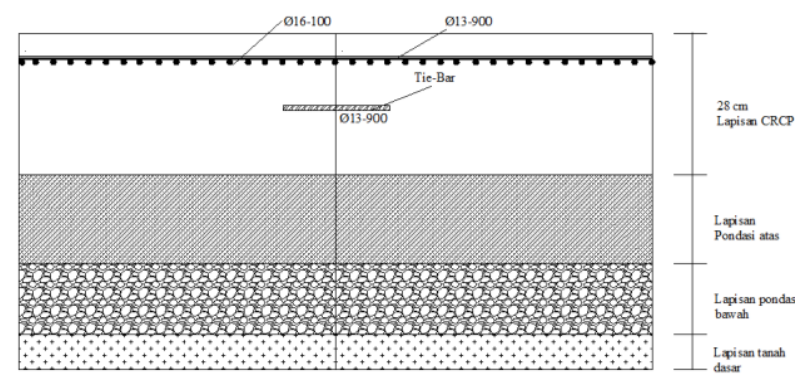

Gambar 3. Potongan Melintang

Perkerasan

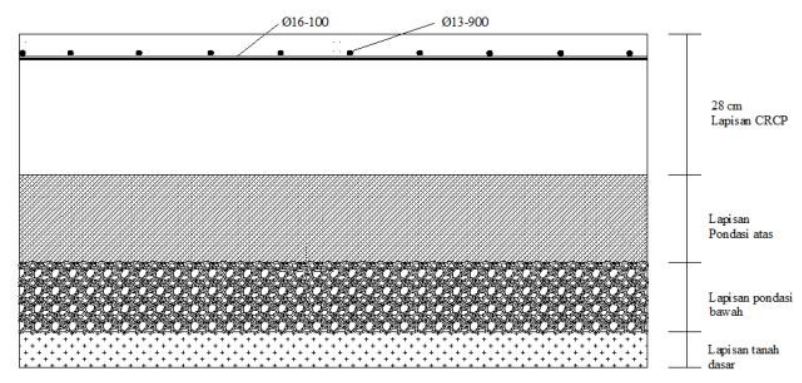

\section{Gambar 4. Potongan Memanjang Perkerasan}

\section{Evaluasi crack pada Perkerasan Existing}

Pada jarak crack didapat 2,98 ft dengan batas minimal 3,5 ft - $8 \mathrm{ft}$. lebar crack didapat 0,027 in dengan batas maksimal 0,04 in. Tegangan baja didapat 37,4 ksi dengan batas maksimal 56,9 ksi. Hasil di atas menunjukkan bahwa perkerasaan eksisting, ditinjau dari retak jarak rata-rata, retak lebar rata-rata dan tegangan baja maksimum berada di bawah batas kriteria dan retak yang terjadi masih terkendali.

\section{Tabel 10. Hasil analisa output Hiperpav Menggunakan Data Eksisting}

\begin{tabular}{|l|r|r|r|}
\cline { 2 - 4 } Time Period to Plot: & Min & Value & Max Unit \\
\hline Crack Spacing Average & 3.50 & $\mathbf{2 . 9 8}$ & $8.00 \mathrm{ft}$ \\
\hline Crack Spacing Standard Deviation & $\mathrm{N} / \mathrm{A}$ & $\mathbf{1 . 4 9}$ & $\mathrm{N} / \mathrm{A} \mathrm{ft}$ \\
\hline Crack Width Average & $\mathrm{N} / \mathrm{A}$ & $\mathbf{0 . 0 2 7}$ & $0.040 \mathrm{inches}$ \\
\hline Maximum Steel Stress & $\mathrm{N} / \mathrm{A}$ & $\mathbf{3 7 . 4}$ & $56.9 \mathrm{ksi}$ \\
\hline Bond Development Length & $\mathrm{N} / \mathrm{A}$ & $\mathbf{1 8 . 9 1}$ & $\mathrm{N} / \mathrm{A}$ inches \\
\hline
\end{tabular}

\section{Evaluasi crack Data Perencanaan}

Pada retak jarak didapat 2,72 ft dengan batas minimal 3,5 ft - $8 \mathrm{ft}$. Retak lebar didapat 0,022 in dengan batas maksimal 0,04 in. Tegangan baja didapat 27,5 ksi dengan batas maksimal $60 \mathrm{ksi}$. Hasil diatas menunjukkan bahwa pada perencanaan perkerasaan, di tinjau dari retak jarak ratarata, retak lebar rata-rata dan tegangan baja maksimum masih dalam batas kriteria dan retak yang terjadi masih terkendali. 


\section{Tabel 11. Hasil analisa output Hiperpav Menggunakan Data Perencanaan}

\begin{tabular}{|l|r|r|r|}
\cline { 2 - 4 } \multicolumn{1}{l|}{ Time Period to Plot: } & Min & Value & Max Unit \\
\hline Crack Spacing Average & 3.50 & 2.72 & $8.00 \mathrm{ft}$ \\
\hline Crack Spacing Standard Deviation & N/A & $\mathbf{1 . 2 7}$ & N/A ft \\
\hline Crack Width Average & N/A & $\mathbf{0 . 0 2 2}$ & 0.040 inches \\
\hline Maximum Steel Stress & N/A & $\mathbf{2 7 . 5}$ & $60.0 \mathrm{ksi}$ \\
\hline Bond Development Length & N/A & $\mathbf{1 7 . 3 2}$ & N/A inches \\
\hline
\end{tabular}

Hasil perbandingan antara data eksisting yang diperoleh dari lapangan dengan data perencanaan memiliki hasil yang berbeda. Dari beberapa kriteria pada tabel 12 data eksisting memiliki hasil lebih besar dibandingkan dengan data perencanaan. Hal ini disebabkan tebal perkerasan data eksisting lebih kecil yaitu $23 \mathrm{~cm}$ dibandingkan tebal perkerasan data perencanaan yaitu $28 \mathrm{~cm}$. Sehingga, dapat ditarik kesimpulan bahwa semakin besar tebal perkerasan beton maka crack yang terjadi akan semakin kecil.

Tabel 12. Perbandingan Hasil Analisa output Hiperpav

\begin{tabular}{|l|l|c|}
\hline \multicolumn{1}{|c|}{ Kriteria } & \multicolumn{1}{c|}{$\begin{array}{c}\text { Data } \\
\text { Eksisting }\end{array}$} & $\begin{array}{c}\text { Data } \\
\text { Perencana } \\
\text { an }\end{array}$ \\
\hline $\begin{array}{l}\text { Jangka waktu } \\
\text { plot }\end{array}$ & 1 Tahun & 1 Tahun \\
\hline $\begin{array}{l}\text { Retak jarak } \\
\text { rata-rata }\end{array}$ & $2,98 \mathrm{ft}$ & $2,72 \mathrm{ft}$ \\
\hline $\begin{array}{l}\text { Standar deviasi } \\
\text { jarak retak }\end{array}$ & 1,49 & 1,27 \\
\hline $\begin{array}{l}\text { Lebar retak } \\
\text { rata-rata }\end{array}$ & $0,027 \mathrm{in}$ & $0,022 \mathrm{in}$ \\
\hline $\begin{array}{l}\text { Tegangan baja } \\
\text { maksimum }\end{array}$ & $37,4 \mathrm{ksi}$ & $27,5 \mathrm{ksi}$ \\
\hline $\begin{array}{l}\text { Pengembangan } \\
\text { panjang ikatan }\end{array}$ & $18,91 \mathrm{in}$ & $17,32 \mathrm{in}$ \\
\hline
\end{tabular}

Sumber: Analisa, 2015

\section{Kesimpulan}

Dari hasil penelitian yang dilakukan pada Jalan Tol Tangerang - Merak STA 34+500 36+300 arah dari Merak - Jakarta, setelah dilakukan analisa juga pembahasan didapatkan kesimpulan yaitu sebagai berikut:

1. Tebal perkerasan beton bertulang menerus dengan menggunakan metode AASHTO 1993 yaitu sebesar $28 \mathrm{~cm}$, sambungan memanjang (tie bar) didapat diameter $13 \mathrm{~mm}$ dengan jarak $900 \mathrm{~mm}$. Hasil perancangan tulangan memanjang menghasilkan diameter tulangan memanjang $16 \mathrm{~mm}$ dan jarak $100 \mathrm{~mm}$ serta tulangan melintang dimeter $13 \mathrm{~mm}$ dengan jarak $900 \mathrm{~mm}$.

2. Dari hasil analisa data eksisting dengan menggunakan software Hiperpav 3.2. Nilai rata-rata jarak retak 2,98 ft dengan standar deviasi 1,49. Nilai rata-rata lebar retak adalah 0,027 in dengan nilai maksimum 0,04 in. Tegangan baja maksimum 37,4 ksi dengan kriteria 56 ,9. Hal ini menjadikan perkerasan eksisting mampu mengendalikan retak. Sedangkan, hasil analisa data perencanaan dengan menggunakan software Hiperpav 3.2. Pada jarak retak didapat $2,72 \mathrm{ft}$ dengan batas minimal $3,5 \mathrm{ft}-8 \mathrm{ft}$. Lebar retak didapat $0,022 \mathrm{in}$ dengan batas maksimal 0,04 in. Tegangan baja didapat 27,5 ksi dengan batas maksimal $60 \mathrm{ksi}$. Hasil diatas menunjukkan bahwa pada perencanaan perkerasaan, ditinjau dari jarak retak rata-rata, lebar retak rata-rata dan tegangan baja maksimum masih dalam batas kriteria dan retak yang terjadi masih terkendali.

\section{Daftar Pustaka}

Anonim. (1993). AASHTO Guide For Design of Pavement Structures 1993, American Association of State Highway and Transportation Officials, Washington, D.C.

Anonim. (2009). Undang-Undang Republik Indonesia Nomor 22 Tahun 2009 
Tentang Lalu Lintas dan Angkutan Jalan. Jakarta

Austroads. (1987). A guide to the Visual Assesment of Pavement Condition Austroads, Australia.

Austroads. (1987). Pavement Design,. A guide to the Structural Designof road Pavement. Design of New Rigid Pavements. Austroads, Australia.

Budianto Ulil Absyor, Agus. (2011). Analisa Pengaruh Kendaraan Berlebih (Overload) terhadap Umur Rencana Jalan dan Kerugian Biaya Transportasi. Universitas Sultan Ageng Tirtayasa. Cilegon

Direktoral Jenderal Bina Marga. (1997). Manual Kapasitas Jalan Indonesia. Pusat Penelitian dan Pengembangan Jalan Departemen Pekerjaan Umum.

Departemen Pemukiman dan Prasarana Wilayah. (2003). Perencanaan Perkerasan Jalan Beton Semen, Pedoman Konstruksi Bangunan, Pd T14-2003. Departemen Pemukiman dan Prasarana Wilayah.

Departemen Pemukiman dan Prasarana Wilayah. (2004). Pelaksanaan Perkeasan Jalan Beton Semen, Pedoman Konstruksi Bangunan, Pd T-05-2004. Departemen Pemukiman dan Prasarana Wilayah.

Pradana, M. F., Bethary, R. T., \& Dewa, G. T. (2013). Studi Identifikasi dan Perencanaan Tebal Perkerasan Jalan Kaku dan Perkerasan Lentur Dengan Metode Bina Marga (Studi Kasus Jalan Kawasan Industri Krakatau Cilegon). Jurnal fondasi, 2(1).

Pradana, M. F., Bethary, R. T., \& Enggalita, T. I. (2013). Perencanaan Kembali Perkerasan Jalan Kaku dengan Metode Bina Marga 2003 Dan AASHTO 1993 (Studi Kasus Ruas Jalan Maja-Citeras). Jurnal Fondasi, 2(2).
Federal Highway Administration. (2006). The investigation, modeling, and validation of the enhanced High PERformancePAVing (HIPEPAV®) II software program, Publication No. FHWA HRT 04-127. U.S Department of Transportation Federal Highway Administration

Federal Highway Administration. (2005). Computer-Based Guidelines for Concrete Pavement Volume II Design and Constraction Guidelines and Hiperpav II user's Manual, Publication No. FHWA HRT 04-122, U.S Depart. Of Transportation Federal Highway Administration

Hardiyatmo, Hary Christady. (2011). Perancangan Perkerasan Jalan dan Penyelidikan Tanah. Gajah Mada University Press. Yogyakarta.

Hardiyatmo, Hary Christady. (2007). Pemeliharaan Jalan Raya. Gajah Mada University Press. Yogyakarta.

NAVFAC DM-54. (1985). Civil Engineering Pavement, Design Manual 5.4, Depart of Navy Naval Facilities Engineering Command, 200 Stovall Street, Alexandria, VA.

PT. Margamandala Sakti. (2013). Spesifikasi Umum Pekejaan Pelebaran Jalan dan Jembatan Ruas Cikupa - Balaraja Barat pada Jalan Tol Tangerang - Merak.

PT. Margamandala Sakti. (2010). Draft Laporan Akhir Perencanaan Rekonstruksi Jalan Tol Tangerang-Merak dengan perkerasan kaku.

PT. Margamandala Sakti. (2014). Laporan Final Analisa Teknis Perkerasan Jalan Proyek Pelebaran Jalan Tol Tangerang Merak.

Rohmah, Siti Hadiyati. (2014). Laporan Kerja Praktek Metode Pelaksanaan Proyek Pelebaran Jalan Dan Jembatan Pada Ruas Jalan Tol Cikupa - Balaraja Barat 
Km. 34+500 - 36+300. Jurusan Teknik Sipil Fakultas Teknik Universitas Sultan Ageng Tirtayasa: Cilegon.

Saodang, Hamirhan. 2004. Konstruksi Jalan Raya. Nova . Bandung.

Suryawan, A. 2009. Perkerasan Jalan Beton

Semen Portland (RigidPavement)Perencanaan Metode AASHTO 1993, Spesifikasi, Parameter Desain, Contoh Perhitungan, Beta Offset, Yogyakarta. 